\title{
Pak-American Interest in Democratic Afghanistan Post Election 2014
}

\author{
Muhammad Ibrahim (Ph.D Scholar) \\ Lecturer Govt. Postgraduate College Bahawal Nagar \\ Email: prof.ibrahim69@yahoo.com
}

Professor Dr. Razia Mussarat

Chairperson, Department of Political Science, Islamia University Bahawalpur

Doi:10.5296/ jpag.v4i4.7188 URL: http://dx.doi.org/10.5296/ jpag.v4i4.7188

\begin{abstract}
Pak-America has interested in democratic Afghanistan. The global community has focused on reconstruction and reformation of national institutions for formulation of institutional policies. The democratic model of governance deals democratic institutional development. The global community facilitated security issues in the Afghan for presidential elections 2014. American and NATO forces decided to evacuate Afghanistan after transfer of power post-election 2014. The purpose of paper is definitive objectives of democratization in Afghanistan. Pakistan suffered socially, economic and politically especially in tribal areas as a neighbouring country. Afghanistan based terrorist organization attacked twin towers of U.S.A. The implication of study will support for guidance at the issue of terrorism which has intense effect on civilized world. The descriptive analysis used as tools of research for accomplishment of paper. The findings become helpful in developing awareness in masses for democratization in Afghanistan. The vibrant role of media strengthened democratic institutions which lessened extremism in region. The paper will explain historical context and different political and democratic transformation eras in Afghanistan.
\end{abstract}

Keywords: Historical context of Afghanistan, Foundation of Institutions, Post2014 Political Transition, Pak-Americans interests 


\section{Introduction}

Afghanistan is being a land lock country having part of an aggressive region. Pakistan has directly or indirectly serious engendered and grave concerns for peace and security since independence. Afghanistan always remained victim of super powers in history. USSR forces intervened in 1980s in Afghanistan. 9/11 incident happened in USA which dragged on issue war of terrorism. Different extremist and terrorist groups used Afghanistan land for terrorist activities in neighbour countries. The modern world has to respond and made alliance against wave of terrorism. Pakistan and America is victim of Afghanistan. After 9/11 NATO and American allies has sent their troops in Afghanistan. These joint military forces conducted operations against terrorists in Afghanistan. As a result, there is a destruction of country. Now these states want to provide assistance in terms of peace building measures.

Different non-state actors gathered and participated in international forum such as Bonn agreement, Tokyo conference, Berlin conference, Chicago-NATO summit and Paris conference. There are conferences, seminars, summits took place for rehabilitation, rebuilding and restructuring of Afghan national institutions such as national police and army. The training of afghan police and army is request for strengthening of state institutions. The donor agencies, international institutions and developed countries improve institutions and infrastructure for involvement of masses in democratic process. The global community is bringing reforms in political and democratic institutions by constitutional methods. It is evidently clear from the 2014 presidential election of Afghanistan. Post-election 2014 political unrest gyrates on the issue of rigging. The confrontation started between Abdullah Abdullah and Ashraf Ghani which resolved under influence of USA.

Al Qaeda and its allies provoke political unrest in Afghanistan. The patterns to maintain peace and security have changed continuously which has affected neighbouring regions specifically Pakistan. The state of insecurity and bone of contention prevailed between Pakistan and Afghanistan due to intervention of the global powers. On the other hand the approach towards maintaining peace and security after $9 / 11$ changed because of the changing trends in international system.

Afghanistan is trying to adopt different trends to maintain peace and security in the country which have tremendous undergone change with the time and situation. Moreover Afghanistan and specifically the South Asian region have been of great interests to global powers due to her geopolitical significance as the great game between Great Britain and Soviet Union. Likewise Pakistan and America has momentous interests in democratic Afghanistan.

\section{Literature Review}

Steffen, Erika, Samuel and Helene (2012) discussed future scenarios regarding the future stability of Afghanistan. They stressed upon American wish to keep back some troops post 2014 in Afghanistan to prevent the revival of Taliban and future insurgency. These incidents have effect on Pakistan stability. Humera Iqbal, in her article discussed Pak-Afghan political cleavages and their bilateral ties since 1947.Moreover touches the geographical and strategic cooperation between both the countries. Then put a beam of light upon Pak- US cooperation against terrorism. Malaiz Daud (2014) discusses the briefing paper in to two parts. The part first will comprise upon historical context of Afghanistan. The second part encircled the issue of five presidential candidate's tickets. These candidates considered as main contenders for presidency. Their runs mates will be analyzed. Zekria Barakzai (November, 2013) explained the significance of Presidential and Provincial council elections in Afghanistan in 2014. The author also put emphasis upon the free, fair, universal and secret elections should be held also explained the reforms in IEC and ECC facilitate the upcoming political transition. Kenneth Katzman (April9, 2014) in the congressional research paper discusses the historical political context of Afghanistan. The author also explains the future challenges for Afghanistan and beyond 2014 elections. Khalid Aziz (September, 2013); the author defines the set of five pillars for the complete political transformation in Afghanistan. He also explains the complications of Pak-afghan bilateral ties as the result of withdrawal of foreign security 
troops by strengthening Afghan National Security Forces. Kenneth Katz man (May 2014) discussed significance of Bilateral Security Agreement and the interests of the international community to stay further in Afghanistan in his report.

Thomas-rutting (2013) expressed the future complications towards United States of America's interests and strategies to leave the bleeding wound ground after post 2014 elections results. Scott-Smith (April, 14 2014) explains the day of presidential election and its results which will be expected more positive as the result of high turnout in elections. The independent election commission also declare in its partial result the voter turnout will expect more the seven million. Mirwais Harooni and Jessica Donat (2014) explain the women participation in elections 2014 of Afghanistan, and the future consequences of women political participation either positive or not. Munir Akram (2014) defines the term democracy and its significance. He stated these afghan elections represent the sign democracy by the tremendous participation of the afghan people. Safiya Aftab (2013) in her briefing paper discusses the future prospects for Pakistan after the exit of ANSF. She also explained the future consequences for Pakistan security, economy and culture post-2014 period.

Noah Coburn (2014) highlighted the future of Afghanistan after the day of April 5, 2014 in terms of security, peace and sustainability of the country. Hafiz Muhammad Irfan (29 April 2014) Dr Noor ul Haq and Nuzhat Khanum (2007) Talal Hussain Afghanistan's multifarious situation andits implications in political, geographical, and turbulent historical situation of Afghanistan on Pakistan have been discussed. The geostrategic position and complications for the bordered areas region are also mention. Frederic Grare (2014) clearly defines the Afghanistan fate after elections 2014 and forecasting the political future of Afghanistan on the basis of voters turns out also further their expectancy in future. Project by Heinrich Boll Stiftung and Center for American Progress April 2013. Afghanistan 2014 Elections update by NDI (2014, March)AyazGul (2014) W. Palmerless (28 March 2002) Rateb Noori defines elections reforms in election commission as an institution. On the other side it is argued that the expectancy of the 2014 elections on the basis of voters' turnout the leading position holder will be Abdullah one of the candidate but the question is arises why he wants bycott from the election.

\section{Historical Context of Afghanistan}

Afghanistan is as a modern state which founded in 1747. It is happened after agreement between Great Britain and Russia in 1893. The river Oxus decided as the northern line of Afghanistan. The Durand line is established in 1893.The line demarcated boundaries of sub-continent with Afghanistan. It is decided between Russians and British Empires of subcontinent Sir Mortimer Durand. (Hassan, N.A, p. 12)

Malaiz Daud narrated multiple upheaval in Afghanistan resulted factors horrible poverty. The super powers made intervene in weak states. The existence of imported non-state actors makes an illicit micro economy of state which is the cause of poverty and illiteracy. The country continuously whirls from colonial era which is established by British and Russian in nineteenth century. It is resulted a proxy wars against Soviet Union in the leadership of United States with its western associates in 1980 that leads to a vicious civil war in 1990s in Afghanistan. During 1990s a civil war broke between different groups. This civil war leads to creation of Taliban in Afghanistan. Meanwhile surprisingly it is observed about the occurrence and manifestation of broad array of political groups and parties in Afghanistan. (Daud, 2014, p. 2)

Pak-Afghan bilateral liaison has been a victim due to conflict of interests in the region. Both countries are having a long historical perspective that is far beyond the partition of Hindustan. Pakistan itself alienated from neighbour country Afghanistan since independence from English. Afghanistan opposed membership of Pakistan in UNO. The Durand line issues bone of contention in Pak-afghan mutual conflicted ties. That is why Pakistan has special focus on the issue of Durand line in foreign policy towards Kabul. On other hand, the followers of National Congress, Khan Abdul Ghaffar Khanand his brother Dr Khan Sahib raised issue Pakhtunistan. They opposed establishment of Pakistan. Afghan government started 
propaganda validity of boundary line which makes border diffident. This issue constructs multiples uncontainable problems such as illegal border crossings, illicit drugs trafficking, criminal networks strong holds, terrorists sanctuaries and fragmentation of societies in tribal belt.

The relationship between Pakistan and Afghanistan got underwent during former President Hamid Karzai who was elected after the first democratic elections in October 2004.In first tenure of President Hamid Karzai, Pakistan is losing impetus for regional politics. Hamid Karzai is urging to make responsible for chaos of Afghanistan. The situation is changed. Pakistan has becoming frontline state to resolve Afghanistan mess. There is make assurance to provide backing government of Karzai after withdrawal of foreign troops. Pakistan and Afghanistan are looking for a peace and regional stability for healthy commencement for bilateral relationship. Former President Hamid Karzai mostly blamed Pakistan for domestic stagnation and insurgency due to interference of Pakistan. The government of Afghanistan accused upon Pakistan state machinery of harbouring Afghan insurgents to destabilize government authority. The state machinery of Afghanistan proved unable to control the spread of lawlessness. Islamabad has strong respond for the support Kabul to Indian collaboration to Baloch guerrilla movement as well as in FATA region made attempts for creating instability in the tribal areas.(Iqbal, N.A, pp. 1-8)

After twelve years of U.S.-led intervention in Afghanistandue to incident of 9/11, there is a war of terrorism in Afghanistan. The insurgency is although not as influential as it was in 1990 s, but is still flourishing and active. There has been some progress in the social field. It proved sustainable if it would be guaranteed by a functional state. The institutions shaped outcome of Bonn Conference in December 2001 as fragile as ever and popular assurance in structure has disappeared. The brighter future prospect till 2014 is beyond, although billion dollars invested for the reconstruction and development of Afghanistan. The political transition in Afghanistan after 2014 presidential election will bring reforms and reformation in the state democratic institutions. The democratic institutions are established after conduction of election. The elections are tool of democratic process. (Grare, 2014, February, p. 9)

\section{Political Participation for Institutional Development}

In modern democratic Afghanistan, institutional development process is started from Bonn conference. There is an agreement signed Afghan representatives in Bonn at December 2001. The accord emphasized the supremacy of democratic norms, human rights as well as strengthening the rights of Afghan women. The accord framed a road map for formulation of national Afghan government having participation of different afghan groups. The interim authority established for governance till next transitional arrangement of elected government. A traditional Grand Council which is known as a Loya Jirga formulated with encouragement of USA. Two women are appointed to Loya Jirga which is functioning as Interim Authority of Afghanistan. (Palmerles, 2002, pp. 2-4) Habiba Sarabi is only woman who awarded party ticket in election 2014. The former governor of Bamiyan who framed alliance with Zalmai Rassoul wants to be first vice president of Afghanistan. Her annexation is to pull out women from homes to polling stations on polling day to strengthen the Rassoul-Qayuum alliance.(Humayun, 2014, p. 9)

The first democratic elections held in Afghanistan on October 9, 2004.President of United States of America George W. Bush stated about conduction of elections which is a success of foreign policy.It is assumed as a milestone and considered the first step that leads to a peaceful, prosperous, democratic and united Afghanistan (Khanum, November, 2007, p. 5). The tenure of the president of Afghanistan under the constitution is five years which expire on May 21.After the election of five year the date of Wolesy Jirga term ended on June 21. According to constitution elections must be conducted thirty to sixty days prior to these dates for these bodies.(Constitution, 2004) Next Presidential election is held in April 2014.

During Presidential election 2014, the Afghan voters flouted or defied threat of Taliban violence. They participated with motivation for future prospects post-election 2014. The 
people participated in electoral process. There was minimal violence at elections day. Meanwhile, reconciliation might involve compromises that could produce backsliding on human rights; most insurgents are highly conservative Islamists who seek strict limitations on women's rights. (Katzman, April 9, 2014, p. 37)

It is important to observe Afghan's experience's with earlier rounds of polling description in 2004, 2005, 2009 and 201o. These elections substantiate as a step forward for democratization in Afghanistan. These elections provide opportunity for public participation in national electoral process for development of democratization. The developing countries have plague experiences of corruption in electoral process. They actively contributed to a sense of political inequality for citizens who feel about Afghan political elite or the international community manipulation of their votes. It is clear that political figure as brokers in Afghanistan from local to national level to adopt electoral system learn how electoral structure can be manipulated. The electoral process used for selection of corrupt leadership. The winning positions can be secured with financial corruption. Afghan government institutions and the international donors have learned a good deal from previous elections about how to manage the transparency of electoral system in Afghanistan. They have struggled to reduce growing levels of corruption in electoral process for institutional development. (Coburn, 2014, pp. 2-3)The democratically elected government in 2009 marks the period of democratization albeit the 2009 presidential election was massively rigged, despite a strong international security and monitoring tools.(Grare, 2014, February, p. 7)

The political awareness for democratic process is seen on polling stations. It is observed that Afghan women wait to cast their ballots at a polling station in a line in Mazar-i-Sharif. These lines of female voters show affiliation with democratic process which is mark as the first democratic election of Afghanistan.(Donati, p. 2) According to the national Electoral Commission of Afghanistan women made up to $34 \%$ of those voting which rose the impressive turn out as a success of global community. That is why Afghan and Western political leaders entitled Afghanistan's presidential election a pathway of democracy. William Hague the foreign secretary of UK stated, "It is a great achievement for the afghan people that so many voters, men and women, young and old, have turned out in such a large numbers, despite threats of violence, to have their say in the countries future." Mr Rasmussen congratulated to voters Afghanistan either male or female who have casted their votes elections with such enthusiasm. Chief of Election Commission commented in such way that clear message conveyed to enemies of Afghanistan. With this determination of the honourable people of Afghanistan, the enemies were defeated.(N.A, 2014, pp. 3-6)

According IPS's Guiliano Battiston and quotes from one of Martine Van Bijlert's, "The Afghanistan presidential election is turning out a tale of two narratives. The more positive and democratic one could be winning the day". All it will possible the only reason which facilitates its success remains massive participation of voters in Afghan elections 2014, approximately the voter turnout will gradually raise the graph of the elections results compare to earlier elections. (Thomas-rutting, 2014, p. 1)

Different scholars argued that the situation of security will determine voter turnout, especially in southern and eastern provinces and women participation will be most at risk if security cannot be provided. That is why international security and national security forces provided secure environment on polling day. In order to ensure a peaceful transition presently armed opposition groups should participate in the electoral process if they meet basic redlines, renouncing violence and respecting the afghan constitution. (N.A, 2013, pp. 1-2)

The Afghan women have communicated their firm fortitude and courage in presidential election by casting votes. This political participation in election process marks the destiny of the country with their own hands. The social scientists believe that lengthened participation of women in electoral process strengthens the reliability and legitimacy of presidential elections. It provides support for the restoration of peace and security of country.(Manager, 2014) 
Americans Strategy Shift Post Election2014

2014, Vol. 4, No. 4

After presidential election of 2014 in Afghanistan the Americans strategy regarding their exit from Afghanistan has been shifted. The main goal of the United States of America remains to stop further transformation and rebirth of Taliban. Kabul is becoming a haven of the global terrorists. The question arises in the minds and hearts of people why Americans troops should leave Afghanistan. Afghanistan is facing challenges in future. Afghanistan is a backward and a dependent state of global communities particularly U.S.A. Regarding military and financial aid the present domestic revenue of Afghanistan is approximately $10 \%$ of GDP.

The political scholars expected growth rate GDP will not rise abruptly it is a slow and steady process that's why Kabul remains fragile to fulfil the needs of Afghan National Security Forces due to lack of military and economic aid. That's why post-election 2014 stability of Afghanistan will maintained by Afghan National Army and ANSF who are heavily dependent on foreign aid. Some scholars argue that the survival and future of Afghanistan remains in the hands of international community specially U.S.A. This is the reason behind the long term stay of U.S.A coalition security forces and military troops to strengthen the Afghan security forces and institutions to make successful 2014 presidential elections also rooted out the Taliban completely before their complete withdrawal. (Stefan Olsson, April, 2012, pp. 7-9)

On the other side the interest of the Americans to stay further in Afghanistan remains to protect the heart of south Asian region from recapturing through global state and non- state actors. It is explained about American perspective as that Americans military troops and International security assistance forces left Afghanistan. There is a power vacuum may develop and the Taliban's with non-state actor try to fulfil it with surrounding actors. That's why Americans will decided to leave Afghanistan after the coming into power of the new president through hold complete fair and free elections. The complete withdrawal may occur in 2016 because ANF will continue to need a direct military support after 2014 to prevent the Taliban. Further stated that if it is possible than Pakistan, India, Chin, Iran and Central Asian countries will not have to worry about geopolitical competition on this piece of land. (Stefan Olsson, April, 2012, p. 90)

In Afghanistan after coming in to power of the first democratically elected government two presidential elections have been held but not transfer of power have been held ever. (Wie, 5 March, 2014, p. 3)This is the first time in the history of Afghanistan in the 2014 presidential election it will happen because major participation of the masses accomplish this dream into reality. That is why international community perform their duties very well to bring long term reform in the independent election commission till 2017. Due to establishment of independent election commission provide the trust worthy foundation for political structure.(Larson, March 2013, p. 15)It is also argued political scientists that delay or in decisiveness has catastrophic consequences for this land mark political transition. In the view of global community Afghanistan constitution has no provision regarding the issues which create hurdle in elections that is why global community bring reforms in independent electoral complaint commission which will prove a key and success to2014 elections.(Barakzai, 2013,November, p. 7)

Americans concerns about to leave Afghanistan at end of 2014 have been shifted from above mention reasons. The global community trepidation is about such rumours that president Karzai made an attempt to alter the constitution. The new president might remove them from the growing structure, thereby reducing the power and access to resources. It could facilitate Karzai intentions regarding the constitutional changes. The global community led by U.S. has advised Karzai to change power approach for ever last and leave his term in 2014. There is a sensitivity of scholars that president Karzai has mechanism which facilitate and empower the mujahedeen factional leaders across ethnic lines. That is why Pak- US military campaign objectives to root out religious militants from Southern Afghanistan and Northern Pakistan side would be the absolute dream of the Americans along promotion of security and stability of Afghanistan post 2014.(Stefan Olsson, April, 2012, pp. 62-84) 
The major contribution of global community in Afghanistan to support 2014 afghan election and made an attempt for free and fair elections. The results should have transparent from fraud and rigging. Larson mentioned in report that Afghans do not always use value-laden western political term to define legitimacy. The elections results in democratic countries tend to be judge on the notion of respect and fairness. On the other hand Afghans tend to forecast the overall legitimacy of the elections process on the bases of judgement. Than may ask the question about the elections procedure and how its outcome would affect Afghanistan uncertain political future. Afghans people only give priority to the stability and peace of the country but Americans interlink the idea of stability within reforms in Independent Election Commission.(Larson, March 2013, p. 2)

America being a global partner in collective security forces sojourns further for reconstruction and rebuilding the state machinery. These forces have plane to control the threats and attacks of terrorists rather made an attempts for coming democratic government post 2014 election. The international security forces like ISAF further stayed for security purpose in Afghanistan will remains security threats escalates and creates cross border security problems for Pakistan. The reforming position of electoral commission for 2014 elections expectation of results will become ambiguous in the presence of global forces in Afghanistan. The upcoming president for Afghanistan post 2014 elections either across the ethnic biasness because global community may develop a sense of political participation in a democratic country should be above than ethnic bases, than the dramatic changes in the IEC and ECC would prevent the fraud in elections which will discussed below.

\section{Reforms in Electoral Process: Independent Election Commission and Electoral Complaint Commission}

The international donors are made efforts to ensure that the transparent, free and fair election. Election 2014 held during the continuation of withdrawal of international troops from Afghanistan. The afghan people elected a new President and members of provincial councils. Afghan political elites are concerned with managing the transition from Hamid Karzai to a new elected leader and with preserving their own power and patronage networks.(Coburn, 2014, p. 2)

Afghan authorities requested to United Nations Assistance Mission of Afghanistan (UNAMA)delegated to support body of presidential elections April 2014.It is also requested to UNAMA to support government for strengthening, sustainability, integrity and extensiveness of electoral process. It is requisite for technical assistance for election engagement and as institutional development in Afghanistan. United Nations development programme (UNDP) Enhancing Legal and Electoral Capacity for Tomorrow II (ELECT II) provided assistance for development as an independent election commission of Afghanistan (IEC). It concentrated to provide institutional solidification and capability development. The main objectives is to facilitate national institutions for conducting the credible elections in future and decrease the risk of minimal support for rigging and to ensure the integrity of electoral process which provides foundation of institutional development.(N.A, 2014, p. 1)

There are seven types of elections to be conducted in Afghanistan every four year which are not conducted in a same year. The presidential and Wolsey Jirga elections are held every five years. Elections are generally considered the most complex and expensive events in some country in world. The elections cycle are prescribed in constitution simply not sustainable. The issues of elections will ultimately resolve under the cover of constitutional amendments. There is complexity in amendments procedures. The current political environment will not prove feasible for formal amendments in constitution in near future. It is noteworthy that recently adopted electoral laws and the structural responsibility of law to IEC-ECC some extents describe the problems related to the transparency for elections.(Barakzai, 2013,November, p. 2)

The civil society has selected members of Independent Election Commission and Electoral Complaints Commission.(Weitz, 2014)The independence and neutrality of IEC has great concern in previous presidential elections of Afghanistan. Abdullah boycotted election 2009. 
He blamed for massive fraud in election. He highlighted about neutrality and independence of election commission of Afghanistan. To address these issues political parties, coalition co-operation council is established in September 2012 which consisted of twenty one major political parties. The political parties are demanding for free, fair elections and awarding autonomy and independence to IEC and EEC. (Barakzai, 2013,November, pp. 2-10)

The presidential election 2014is a litmus test for Afghanistan's political culture. Therefore much focused on reforms in elections commission. The independent election commission should be autonomous and comprised of a credible chairperson and commissioners, who are not hand-picked individuals close to current political administration. The international monitoring has key role for free and fair election. It is an important and key factor should not be mistaken of interference by external actors. The observers should also participate from Islamic as well as Western countries. Afghan civil society have to organize and eagerness to contribute in process of monitoring of elections. Global communities support electoral process and concentration has focused on monitoring throughout process. Finally an independent and impartial election complaints mechanism with clear jurisdiction should be established to ensure credibility of vote. (N.A, 2013, p. 1)

The conditions for a successful transition in a stable Afghanistan require appropriate bureaucratic and institutional mechanism to ensure the momentum for change is harnessed and that timely follow ups-take place. The political transition is absolutely significant for a peaceful future of the country. For ensuring the forthcoming presidential elections of April 5 2014 and the provincial, district and municipal elections should be free and fair through electoral reforms and agreements on the structure of an independent election commission and electoral complaints commission. The role of Supreme Court and an Independent Commission for supervision of implementation is defined as a single fool proof and uncontroversial voter registration list by replacing with multiple voter lists. The latter has very irregularities and will undoubtedly ask questions about transparency of upcoming elections. (Aziz, 2013, pp. 1-2)

The IEC releases first batch of primary results which covered 26 provinces out of 34.Theseresults yielded three important conclusions. This is first presidential election 2014 in which president Karzai could not participate. Firstly Afghan people voted for their presidential candidate across ethnic clashes. It is predicted in this election. Secondly Ashraf Ghanigot $03 \%$ votes in previous elections. Now he is runner up in first round and got $37.6 \%$ votes in preliminary count and in second position. Abdullah Abdullah get $41.9 \%$ vote and he is the main competitor to President Hamid Karzai in presidential election 2009. Thirdly, the candidates Zalmai Rassoul extensively assumed support of president Karzai who get only $9.8 \%$. There is a condition to get $50 \%$ to win votes in the first round. Otherwise a competition is held between winner and runner will be held. The peaceful transition of power occurred to elected president of Afghanistan. The transfer of power has never occurred in Afghanistan in the history.It becomes tremendous political transition from one elected President to other President.(Smith, 2014, pp. 3-4)

The chairman of IEC Ahmad Yousuf Nuristani stated in a press conference that the announcement of the partial result be delayed because of incomplete conversation between Abdullah Abdullah and United Nations Assistance Mission in Afghanistan. The discussion on issue of the partial result announcement is happened between UNAMA, government of Afghanistan and Dr Abdullah. The chairman of IEC told that we did not announce the partial results. Nuristani stated that whenever the issues are bit clearer, results will be announced. Nuristani further said that the process of collection of votes is moving forward. Approximately eighty $\%$ of total votes from thirty two provinces have been congregated and entered in to database of commission. (Noori, 2014)

The candidate who leads in first round of presidential elections is made boycott from the final count of votes in final round. He alleged fiddle stimulating a political crisis that threaten stability of Afghanistan. Abdullah Abdullah garnered $45 \%$ votes in first round of elections against ex-finance Minister Ashraf Ghani's 31.6\%. His campaign officials stated that they 
will not accept the result because of the massive alleged fraud. IEC put turnout at more than seven million, a figure disputed by Abdullah and some election observers, who say they believe the actual casting is roughly five million. Mr Abdullah Said, "We spend our engagement with the commission, demanding the removal of the country's chief electoral officer and the creation of a neutral committee to adjudicate his fraud claims", "We are asking for the counting process to be stopped immediately."(Margherita, 2014)

\section{Results of Presidential Election 2014}

It is fore casting Dr Abdullah likely to become next president of Afghanistan but there is one \% possibility that Dr Ashraf Ghani may become president. Constitutionally to be a president of Afghanistan has to secure more than $50 \%$ votes. There are reasons behind the sudden political crisis about elections partial result. One of the competing leader wishes to boycotts the elections, what will be the future prospects for Afghanistan's political history and its impacts on Pakistan. (Irfan, 2014)

The Independent Election Commission of Afghanistan has released partial results about presidential election. The results of first round of voting are incrementally on a rolling basis beginning on April 13. The complete preliminary results were publicised on April 26, and final results were released on May 15. Table shows the results of the first round presidential election, which are giving as following as:

Table No1

Detail of First Round Presidential Election

\begin{tabular}{|l|l|l|l|l|l|}
\hline Candidate Name & $\begin{array}{l}\text { Preliminary } \\
\text { Votes }\end{array}$ & $\%$ & Final Votes & $\%$ & $\begin{array}{l}\text { Difference b/w } \\
\text { Preliminary } \\
\text { \&Final }\end{array}$ \\
\hline Abdullah Abdullah & 2973706 & $44.94 \%$ & 2972141 & $45 \%$ & 0.06 \\
\hline $\begin{array}{l}\text { Muhammad Ashraf } \\
\text { Ahmadzai }\end{array}$ & 2082417 & $31.47 \%$ & 2084547 & $31.5 \%$ & 0.09 \\
\hline $\begin{array}{l}\text { ZalmaiRassoul } \\
\text { Eng- }\end{array}$ & 759540 & $11.48 \%$ & 750997 & 11.37 & -0.11 \\
\hline $\begin{array}{l}\text { QutbuddinHilal } \\
\text { ybdoRabeRasoolSa }\end{array}$ & 180859 & $2.73 \%$ & 181827 & $2.75 \%$ & 0.02 \\
\hline $\begin{array}{l}\text { Mohd. ShafiqGul } \\
\text { Agha Sherzai }\end{array}$ & 106,673 & 1.61 & 103,636 & 1.61 & -0.04 \\
\hline $\begin{array}{l}\text { Mohammad } \\
\text { DaoudSultanzoy }\end{array}$ & 30737 & 0.46 & 30685 & 0.46 & 0.00 \\
\hline $\begin{array}{l}\text { Hedayat Amin } \\
\text { Arsala }\end{array}$ & 15,394 & 0.23 & 15,506 & 0.23 & 0.00 \\
\hline
\end{tabular}




\begin{tabular}{|l|l|l|l|l|l|}
\hline Total & 6617666 & 100 & 6604546 & 100 & -0.02 \\
\hline
\end{tabular}

Source: Independent Election Commission of Afghanistan, http://www.iec.org.af/results/en/elections\#

The final certified result of the presidential run-off is scheduled for announcement on 22 July 2014.(N.A, 2014)

Table No2

Detail of First Round Presidential Election

\begin{tabular}{|l|l|l|}
\hline $\begin{array}{l}\text { Name of Presidential } \\
\text { Candidates }\end{array}$ & Total Votes & $\%$ of Casting Votes \\
\hline $\begin{array}{l}\text { Dr. Mohammad Ashraf } \\
\text { GhaniAhmadzai }\end{array}$ & $4,485,888$ & $56.44 \%$ \\
\hline Dr. Abdullah Abdullah & $3,461,639$ & $43.56 \%$ \\
\hline Totals & 7947527 & $100 \%$ \\
\hline
\end{tabular}

Source: Independent Election Commission of Afghanistan, www.iec.org.af

The policy makers and analysts focus on next president of the country. It has significance to thoughtful about ethnic aspect of Afghanistan. Whether Afghanistan's Pashtun, Uzbek, Tajik, Hazara and other major continues support the election's outcomes. Several Pashtuns candidates have already courted ethnic minority running mates to demonstrate inclusivity and secure support of minority constituencies. These candidates can change their running mates at any point up to elections. That is why the prospects for security have to improve for upcoming elected president and his team receive support. It is also assume that it is not necessary security remained tighten due to the presence of ISAF instead of political consensus, lesser American manpower after 2014 will able to bring peace and security in Afghanistan. In this way the security challenges will be minimize across the border lines which are revolved on ethnic basis. (Jones, 2014, pp. 3-4)

\section{Post 2014 Elections impacts}

The results of drawing back of U.S. led NATO forces from Afghanistan apprehensions about future of the country and its neighbour has been endured. A Palpable sense of pessimism has come to characterize thinking about the situation of Afghan in West, as well as in Afghanistan and among its neighbours. It is presuppose by many scholars that, it may possible that the country may be experience a major political crisis in the result of 2014 presidential elections outcomes either it may well disintegrate along ethnic or other factional lines. The legitimacy of the post-Karzai government will therefore be the decisive element of the evolution of post-2014 Afghanistan, bearing in mind that the current situation, in which the largely discredited government still holds the keys of the forthcoming presidential election, is unlikely to lead to a positive outcome.(Grare, 2014, Feburary, pp. 1,6-7) 
The critical situation of Afghanistan is considered the most influential for neighbour country Pakistan. It is repeatedly blamed in report of DOD about stability of Afghanistan and afghan militant safe sanctuaries in Pakistan. These militants are intimidations for stability of Afghanistan after withdrawal of US led force in 2014. It is considered that Pakistan prodigiously favoured Ghanito be elected as president. He is a Pashtun and a plausible friend for Pakistan. Dr Abdullah is supported by Northern Alliance which is gruffly criticizing Pakistani establishment. Abdullah several times is denunciated Taliban directly and materially seeking power to return in Afghanistan.(Katzman, April 9, 2014, p. 44)

Kate Clark an analyst writes that Sayyaf sponsored U.S. efforts to re-engage Karzai administration in bilateral security agreements which allowed thousands of U.S. forces to stay in Afghanistan after departure of battle troops in end of 2014.The democratically elected forthcoming administration is follow path of Karzai legacy or not. It decides the future prospects towards Bilateral Security Agreements with U.S.A. Due to some sort of short fall of security arrangements in Afghanistan its impacts blowout also Pakistan's security.(Thomas-rutting, 2013, p. 1)According to a preliminary estimate of election commission, it is calculated that seven million vote casted out of twelve million eligible voters. It is observed that about 58\% vote casted in election 2009. As comparison to last presidential election of 2009 , this time vote casting ratio approximately 4.5 million remains low. But in the present political contests president Barack Obama congratulated the Afghan People on the elections and stated that; "we commend the Afghan people, security forces, and elections officials on turnout for today's vote- which is in keeping with the spirited and positive debate among candidates and their supporters in the run-up to the election," he also stated that, "these elections are critical to securing Afghanistan's democratic future, as well as continued international support, and we look to the afghan electoral bodies to carry out their duties in the coming weeks to adjudicate the results- knowing that the most critical voices are those afghan themselves." the U.S. secretary John Kerry stated that, "The United States remains ready to work with the next president of Afghanistan. We will continue to stand with the people of Afghanistan as they work to build a democratic future."(Donati, pp. 3-5)

The departure of majority of ISAF forces from Afghanistan till the end of 2014. It has significant impact for regional states as well as Afghanistan. The neighbour country Pakistan has specific effects for stability. The continuous instability of decades of this region has significant impacts on political and economic activities as well as its security relationship with international community also in tough situation. Pakistan internal dynamics may secure itself from affecting as well as post 2014 presidential.(Aftab, December,2013, p. 1)

Pakistan's post-2014 scenario is rooted in a shared, often deadly, history of conflict spill over. The militant rise of Tehrik-e-Taliban in the tribal belt and its growing sanctuaries in eastern Afghanistan has been shifted Islamabad's stakes in a peaceful transition and Kabul. This existential threat to Pakistan has promoted a civilian-led consensus to push for no favourites, policy in the afghan end game, manifesting itself in unprecedented overtures towards the Northern Alliance. Despite having continuous distrust in Kabul and President Karzai own mercurial finger pointing across the border, the bilateral ties of pak-afghan under the new administration of Kabul will determine regional stability after pulling out of ISAF.(Humayun, 2014, pp. 2-3)

Munir Akram explained the theory of democracy which is a process of governance with popular consent of masses. It is peaceful handover of power realized in election 2014 of Afghanistan. It will prove as hallmark for the political transition and stability of the country. Afghanistan will have status of peaceful and an independent democratic state as the result of elections 2014.The ethnicity could play a more significant role in present elections than 2009. Afghanistan state machinery working with democratic model has deep impacts on security threats for Pakistan. It focused on future prospects towards cross border issues of PakAfghanistan.(Akram, 2014, p. 1). (Weitz, 2014)

The first political transition in democratic way in war ravaged country. According to UNAMA, it is warned that till the final results declared by authorities of election commission, 
"Stakeholders should be careful in drawing premature conclusion so as not to create inaccurate expectations." (Gul, 2014) The situation of security is worsening still. There is an incident of attempt of assassination of Abdullah Abdullah. He stated, "It was a big conspiracy against me", because my car was targeted (N.A, Afghanistan Candidate Escape from Assassination Attempt). Such attempts create harassment and chaos in the country. There are major challenges of cross border security to Pak-Afghanistan.

It is concluded that Afghanistan future may remain in the control of global community. It is realized that the trained national security personnel have no still maximum capacity for the stability of country. The changing pattern of international community is further stay in Afghanistan post 2014 election. The critical situation is how much expected government of Afghanistan will maintain their ties with Americans with new security accord with new objectives to secure Afghanistan from terrorist's threats. Being an adjacent country Pakistan facing multifaceted challenges especially towards the arena of security. Pakistan perceives many challenges in terms of economic, political and social due to migration of afghan people after NATO- led invasion in Afghanistan. The primary concern of Pakistan is forecasting regarding the afghan 2014 presidential elections result and establishment of new government (that has now established).Pakistan desires remain that the upcoming president of Afghanistan should be elected beyond the ethnic linkages because it may harm their bilateral relationship and affect the policies of government of Pakistan for the regional stability. The present situation of Afghanistan after announcing partial results of the election as the result annoy one of the expected leader and nurture the question about the neutrality and transparency of electoral commission also upon the global community who bring reforms in electoral commission institution.

\section{Conclusion}

The bones of contention between states engender due to their geostrategic position and other combating interests. It is compulsion on global powers, donor agencies and global institutions have attempted to order the peace and stability in world based on democratic values.States remain firm and steady on condition when their culture, norms and institutions are based on democratic ideals. Democratization through reconciliation and reorganization is the reason behind the foundation of global institutions. The democratic ideals should be adapted for regional sustainability.

Afghanistan's fate twisted under the influence of global powers. USSR, Britain and America desired to conquer with intervention to deal its internal and external matters. Afghanistan faces multiple challenges and threats towards its stability and sovereignty.

Pakistan is an independent and sovereign state, but its stability always remains dependent upon its neighbouring position. The military operations and terrorists attacks forced masses flight for refuge in tribal areas of Pakistan. Pakistan has to suffer grim and grievances socio-political and economic issues such as refugees problem, internally displaced persons, terroristic attacks, military operations, loss of business and foreign investment, reversal of democratic behaviour and growth of extremism (ethnic and sectarian violence), division of military resources and efforts for mechanization, training and advancement of security institutions and forces, loss of valuable lives and destruction of infrastructure worth billions of rupees. Pakistan present crisis of security is creating political unrest. The policy of global community for peace and security in South Asian region is similar due to their geographical position.

There is lack of matured national institutions to establish democratic system. The traditional values of society also become hinder in the development of democracy in Afghanistan. The purpose of this reconstruction was to make Afghanistan a stable democratic state and for this it was necessary to reform the institutions such as electoral commission.

Global communities also opt the approach of constitutionalism for other South Asian states like Pakistan. Pakistan needs to overcome its political crisis as soon as possible in lies with principle of democracy and remaining within the bounds of a democratic constitution. 
Because democracy means the government of the people so a democratic state needs to maintain peace and security by overcoming their challenges through reconciliation, reconstruction and reorganization of institutions so as to strengthen democratic norms and values for permanent peace and security; democratic constitution, institutional domain with the concept of separation of power, checks and balance is the only way out.

\section{Bibliography}

Aftab, S. (December,2013). The 2014 ISAF pullout from Afghanistan: its impacts on Pakistan. Norwegian Peacebuilding Resources Centre.

Akram, M. (2014, April 7). Democracy's darker dividends. Retrieved from http://www.dawn.com/news/1102539

Aziz, K. (2013). Five Pillars of a Successful Transition in Afghanistan 2014. DIIS Policy Breif.

Barakzai, Z. (2013,November). 2014 Presidential and Provincial Council Elections in Afghanistan. United States Institute of Peace .

Coburn, N. (2014, Feburary). Looking Beyond 2014: Elections in Afghanistan's Evolving Political Context. AsiA programme Afghanistan: Oppertunity in Crisis Series No.1 .

Daud, M. (2014, Feburary). Sources of Tention in Afghanistan and Pakistan: A Regional Perspective The Political landscape of Afghanistan and the Presidential Election of 2014.

Donati, M. H. (n.d.). Releif in Afghanistan after largely Peaceful landmark election. Retrieved from http://www.reuterus.com/article/2014/04/05/us-afghanistan -elections

Grare, F. (2014, Feburary). Afghanistan Post-2014: Scenario and Consequences. Journal of Transatlantic Council.

Gul, A. (2014, April,13). Partial Afghan Elections Put Abdullah in Lead. Retrieved from http://www.voanews.com/content/reu-partial-afghan-election-results-put-abdullah-abdullah-i n-lead/1892324.html

Hassan, T. (N.A). Afghanistan Complex Situation And its Impacts on Pakistan. Retrieved from http://dspace.mah.se/bistream/handle/2043/1076/final\%20thesis.pdf

Humayun, F. (2014, April 6). Afghanistan's Presidential Elections 2014. Retrieved from http://www.jinnah institute.org/afghanistan-presidential-election-2014/

Iqbal, H. (N.A). PAK_AFGHAN TIES IN THE LIGHT OF PAK_US STRATEGIC DIALOUGE. Retrieved from http://www.irs.org.pk/afghanistan/spin10.pdf

Irfan, H. M. (2014, April 29). Afghanistan's Presidential Elections. Retrieved from http://www.dailytimes.com.pk/opinion/24-Apr-2014/afghanistan-presidential-ElectionsFinanc ials

Jones, S. G. (2014). Presidential Candidates Need Multiethnic Consensus. Retrieved from http://www.cfr.org/afghanistan/prospects-afghanistan-2014/p32094?cid=rss-development prospects for afgin2-121813

Katzman, K. (April 9, 2014). Afghanistan:Post-Taliban Governance, Security, and U.S. Policy. Congressional Resarch Services.

Khanum, D. N. (November, 2007). Afghanistan Presidential Election 2004. IPRI Fact Files.

Larson, N. C. (March 2013). Justifying the Means Afghan Perception of Electoral Process . United States Institue of Peace. 


\section{Macrothink}

Journal of Public Administration and Governance

ISSN 2161-7104

2014, Vol. 4, No. 4

Manager. (2014, April 1). Afghan Women Determined To Vote In Elections. Retrieved from http://www.bakhtarnews.com.af/eng/elections-93.html

Margherita. (2014, June18). Afghan Candidate Bycotts count of Votes. Retrieved from http://www.wsj.com/articles/ab-alleges-bias-at-afghan-elections-watchdog-1403089667

N.A. (2013, April). Afghanistan beyond 2014: Elections, Political Settelment, Reforms, Recomendations from Afghan Civil Society. project by Heinrich Boll Stiftung and Center for American Progress.

N.A. (2014, April 6). Afghanistan Presidential Poll Hailed as a Success. Retrieved from http://www.bbc.com.news worldasia-26908464

N.A. (N.A.). Afghanistan Candidate Esacape ffrom Assassination Attempt. Retrieved from http://wwwnews.com/world/afghanistan/candidate-escape-assasination-attempts

N.A. (N.A.). Afghanistan Presidential and Provincial Council Elections. Retrieved from http://www.unama.unmission.org/Default.aspx?tabid=13936\& language

Noori, R. (2014, June 21). Partial Results of Runoff Elections Delayed. Retrieved from http://www.tolonews.com/elections2014/partial-results-runoff-elections-delayed

Palmerles, W. (2002, March 28). The situation of Women in Afghanistan. Retrieved June 2014, from http://2001-2009.states.gov/g/wi/9118.htm

Smith, S. (2014, April 14). In Crucial Afghan Elections, Signs Democracy Is Taking Hold. $\mathrm{http} / / /$ theglobalobservatory.org/analysis/718-in-crucial-afghan-elections-preliminary-signs-de mocracy-could-take-hold.html.

Stefan Olsson, E. H. ( April, 2012). Afghanistan After 2014 Five Scenarios. report No, FOI-R-3424-SE ,Stockholm.

Thomas-rutting. (2013, November 17). How Will Afghanistan Elections Affects U.S. interests? Afghanistan Analyst Network.

Thomas-rutting. (2014). Afghanistan Turns a Political Corner. Afghanistan Analysis network.

Weitz, R. (2014, May wednesday). Afghanistan National Election Exceed Expectations. Retrieved from http://www.cacianalyst.org/publication/analytical-articles/items/12969-afghanistan-national-e lections-expectations.html.

Wie, S. V. ( 5 March, 2014). Elections in Afghanistan: What's At Stake For Women. George W Bush Institue. 